\title{
Managing Emotional Labour in Service Encounters in Healthcare Occupation in Bangladesh
}

\author{
Muhammad Faisol Chowdhury \\ School of Business, North South University, Dhaka, Bangladesh \\ Email: faisol.chowdhury@icloud.com
}

Received 23 September 2014; revised 24 October 2014; accepted 25 November 2014

Academic Editor: Luca Solari, University of Milan, Italy

Copyright (C) 2014 by author and Scientific Research Publishing Inc.

This work is licensed under the Creative Commons Attribution International License (CC BY). http://creativecommons.org/licenses/by/4.0/

(c) (i) Open Access

\begin{abstract}
This conceptual paper discusses the management of the emotional labour of front-line customer service employees of public and private hospitals in Bangladesh. This paper recognises the link between service encounters and customer satisfaction, and critically discusses the concepts of emotional labour, soft skills and aesthetic skills in an attempt to explain the problems associated with the use of these terms. By providing some recommendations about overcoming the challenges of managing the front-line employees, this paper suggests that the appropriate management of emotional labour and aesthetic skills through the implementation of Human Resource Management practices illuminates the organisation's route to success.
\end{abstract}

\section{Keywords}

Emotional Labour, Aesthetic Skill, Soft Skill, Human Resource Management, Healthcare Occupations

\section{Introduction}

"It is only at the first encounter that a face makes its full impression on us" (Arthur Schopenhauer).

This century old proverb by the German philosopher is still reaffirmed by the majority of customers during service encounters. For service organisations, the interaction between the front-line personnel and the customers is crucial, as they aim to create high quality service encounters [1]. Yee, Lee, Yeung \& Cheng [2] and Zeithaml \& Bitner [3] identified that organisations that focused on customer satisfaction were able to build loyal clients 
who then served to promote the organisations further through vital word-of-mouth advertising referrals. Correspondingly, empirical studies have found a correlation between high quality service encounters and organisations' success and survival in the healthcare sector [4] [5]. In developed countries, healthcare centres have been increasingly using higher quality customer service to satisfy their patients [6]-[8]. The study by Nickson et al. [1] found that the majority of employers viewed their front-line employees as offering a competitive advantage in relation to both the delivery and quality of their services. As a result, employers place significant importance on managing employees' emotional labour, and "soft" skills which encompass social, interpersonal and aesthetic skills [1] [9].

In context of Bangladesh, the problem of peoples' access to healthcare is acute in both the urban and rural areas. The ever-growing population placed a greater demand on the country's healthcare services. To address this pressure, private healthcare sector was given the opportunity to play a wider role in the provision of medical services through the promulgation of the ordinance of 1982, alongside the government's increased allocation for public hospitals establishments [10]. In the past two decades, Bangladesh has seen the growth of private and public hospitals and medical centres across the country. As of 2010, there are about 42,237 hospital beds in the private hospitals compared to 30,176 beds in the public hospitals [11]. With this significant increase, many researchers have attempted to assess the quality of the services delivered by the front-line customer service personnel of these establishments. In particular, many empirical studies have sought to identify the differences between the customers' actual experiences of the service encounters and their expectations.

Given the important link between service encounters and customer satisfaction in the interactive service sector, this paper critically examines some of the challenges facing the management of the front-line customer service personnel of public and private hospitals in Bangladesh. In particular, it discusses the concept of emotional labour, soft skills, and aesthetic skills, and then attempts to explain the problems associated with managing these terms. The paper, through further examination, then highlights some of the recommendations for overcoming these challenges.

\section{Emotional Labour, Soft Skills and Aesthetic Skills}

Customer service in healthcare centres are an interactive occupation that requires substantial psychological involvement of the part of the front-line personnel due to the inherent vulnerability and trusteeship associated with the job role, as well as the uncertain and unstable emotional state linked with the customers who are mainly patients and their visitors. As such, this occupation necessitates font-line employees' engagement in a high-level of emotional labour in order to manage the emotional and physical needs of the customer. Emotional labour in interactive occupation is an important concept because it has been linked with employee outcomes such as job dissatisfaction, burnout and retention [12]-[14], which in turn could have a significant effect on customer satisfaction and business revenue [15] [16]. Pioneering the concept of emotional labour, Hochschild [14] explained that it requires employees to induce or suppress their emotions in order to generate a visible facial and bodily display that produces a desired emotional state in the customer. Observably, in most interactive service occupations, attitudinal restructuring focuses on managing employees' feelings while they are at work, which often gives rise to the need for front-line employees to engage in emotional labour, involving the suppression or engendering of certain types of emotion [14] [17].

Similarly, a number of researchers have claimed the importance of employees possessing soft skills in interactive service occupations. They identified soft skills as social and interpersonal skills which are largely concerned with ensuring that front-line employees are responsive, courteous and understanding towards customers [1] [18]. Hurrell et al. [9] defined soft skills as those which involve dealing with managing oneself, one's emotions, and other people, in a manner consistent with particular workplaces and organisations. In spite of the growing prominence of soft skills in the interactive service sector, there is an ongoing debate about defining and characterising this type of skill, and whether or not soft skills can be considered a skill type [19] [20]. To address this debate, Hurrell et al. [9] further tackled soft skills by strengthening the conceptual understanding of them by examining of how these skills are used in different contexts. Bolton [21] similarly implied that work that is reliant on soft skills is indeed skills. Fleming, Harley \& Sewell [22] claimed that any soft skill has knowledge involved in it and so all soft skills are in fact skills. Furthermore, by arguing that the description of soft skills is partial, Nickson, Warhurst, Witz \& Cullen [23] suggested that "aesthetic skills" represents employees' appearance and behaviour — the "ability to look good and sound right" [1]. With good look and good behaviour, 
front-line personnel potentially offer a competitive advantage in relation to both the process of service and the service encounter, and equally become an integral part of the tangible product embodying the image of the company [24].

\section{Customer Satisfaction with Healthcare Services}

Interwoven with the quality of the front-line customer service personnel is customer satisfaction-an important but grossly neglected measure of performance in the healthcare sector in Bangladesh. The overall quality of the healthcare services, including the customers' experiences with the front-line executives, have often been criticised [25]-[27]. The empirical studies that compare the service encounters between private and public hospitals conducted by Akter, Upal \& Hani [28], Siddiqui \& Khandaker [25], and Andaleeb [10] [29] showed that, although the customer experiences during service encounters are dissatisfactory in public hospitals, the level of satisfaction is far higher in private hospitals. The theoretical basis of this finding is that the quality of customer services provided by the hospitals is contingent on market incentives. Since private hospitals are not subsidised and depend on the clients' income, they are more inclined towards offering better customer service to meet their patients' needs [29] [30]. By doing so, private hospitals are able not only to build a pool of satisfied customers who revisit them for future treatment, but also to use their customers as a source of referrals that recommends the hospitals, thereby sustaining the long-term viability of the hospitals. Similarly, the perception of the poor quality health services offered by public hospitals discouraged patients from using their available services because health concerns are among the most salient of human concerns [10]. In public hospitals, there is little or no market incentive to motivate their front-line personnel to take the extra initiative to improve the customer experience during service encounters [31]. Therefore, despite the high personal cost of seeking treatment in private hospitals, people tend to do so.

It is also observable that considering both the public and private hospitals, healthcare customer develop perceptions of hospitals in terms of the attributes that are embodied in them. Some of these attributes are deemed more important than others in a choice of hospital. Empirical evidence reveals some individual items that influence hospital choice by customers positively or negatively. For example, a well equipped emergency section, offering timely and high quality medical care delivered by specialists, human behaviour and interpersonal communications of the hospital staffs are some of the important aspects influencing patients' choice of hospital. Evidence shows that, medical staff in private hospitals were perceived to be more skilled, helpful and had a more pleasant attitude regarding patient needs [32].

\section{Managing Emotional Labour and Aesthetic Skills in the Healthcare Occupation}

In managing employees' emotional labour and aesthetic skills during service encounters, it is firstly important to determine the criteria on which service encounters should be assessed. Zeithaml \& Bitner (2003) [3], Andaleeb (1998) [33], and Babakus \& Mangold (1992) [34] suggested that service quality in healthcare can be defined in terms of the relationship to technical aspects of care, the interpersonal relationship between the hospital workers, medical practitioners and patients, and the amenities of care. Anbori, Ghani, Yadav, Daher \& Su (2010) [35], Siddiqui \& Khandaker (2007) [25] and Carrillat, Jaramillo \& Mulki (2007) [36] used the popular SERVQUAL framework developed by Parasuraman, Berry \& Zeithaml (1991) [37] to measure the quality of service encounters. Conversely, Babakus \& Boller (1992) [38] and Carman (1990) [39] demonstrated several shortcomings of the SERVQUAL scale and suggested the modification, deletion or introduction of new dimensions of its scales in order to better study the customer service quality of hospitals. Zeithaml \& Bitner (2003) [3] formulated the Gaps model for service quality assessment. In recent times, DEA (Data Envelopment Analysis), qualitative questionnaire and statistical analysis based on retrospective data have been approaches employed by researchers to assess the service quality in healthcare [31] [32] [40]. Furthermore, the assessment of the quality of the service encounters was previously delegated to the medical professionals and was defined by clinicians in terms of the technical delivery of the care. More recently, patients' assessment of service encounters and the quality of care have begun to play an important role in advanced countries, and satisfaction and dissatisfaction with service encounters have become an important area of enquiry in relation to the overall service quality provided by the hospitals [41].

Considering this discussion, it is necessary to highlight the challenges faced by Bangladeshi hospitals with regard to managing the emotional and aesthetic labour of their front-line personnel. Firstly, there is the issue of 
efficiency with regard to the generating of profit by these establishments. As briefly highlighted earlier, private hospitals are dependent on their clients' income, and Chowdhury (2009) [42] and Paul (1999) [43] found that the majority of high-earning professionals (academics, doctors, engineers, lawyers, bankers), and wealthier businesspeople prefer private hospitals due to the overall better service quality they provide. They seldom visit public hospitals, and then only as a last resort, as these cannot not generate a threshold level of quality for them. This is one of the main reasons for the income efficiency of private hospitals, which enables them to hire, train and develop a pool of smart, educated young graduates as front-line executives. This also enables them to hire reputable physicians from the public hospitals and even from abroad as a means of advertising to their patients to increase their patient flow and revenue [31]. Secondly, researchers have also revealed that, on the one hand the government's allocation of funds to the public hospitals is insufficient, and on the other, mismanagement and corruption have made the financial crisis even more acute so that investing money in acquiring qualified staff and training is avoided due to funding constraints [44] [45]. As a result, public hospitals face a deficiency of skilled, educated staff, a poor salary structure, reduced managerial control, and a lack of training options for the career and personal growth of their front-line staff [46].

Thirdly, the phenomenological study of Chowdhury (2009) [42] unfolded a number of factors in addressing emotional labour and aesthetic skills among the front-line executives of public hospitals. His research showed that, most of the time, customers felt unsafe when carrying out monetary transactions with the front-line staffs. These staff were not consistently courteous and sincere during service encounters, and in most cases did not have the knowledge to answer customers' technical questions [42]. Customers were not given individual attention and the staff failed to understand their specific needs [42] [43]. Similarly, it was also pointed out that the customer service staff neither wore a uniform (given that, in some government hospitals, a uniform is supplied to all front-line staff) nor had any professional or neat attire [42]. These incidents confirm the level of weakness among the hospital administration, where understanding the value of quality service and failing to provide customer service training result in an unsatisfactory level of service encounters. These researchers further mentioned that, ironically, the customers' viewpoint was neither sought nor given any importance in the public hospitals, unlike in their private counterparts, where customers' feedback was frequently taken into consideration to improve service encounters [28] [29] [42].

Another problem is managing the impact of emotional labour and aesthetic skills on employee burnout and turnover. Researchers found a positive relationship between a high level of emotional labour and job burnout, which results in a low employee retention rate [47] [48]. Customer service in hospitals requires the front-line employees to be highly empathetic when dealing with patients and their visitors. The unique ability to read customers' mind and observe their body language to show appropriate behaviour is very important in this occupation. Identifying this requirement, the majority of private hospitals in Bangladesh, located in the metropolitan cities have been found to provide adequate training to their service personnel to offer assistance to happy or distressed patients in a sensible manner [25] [42]. Through providing proper training, adequate incentives, and an employee assistance plan, these hospitals also enjoyed a high employee retention and less job burnout [42] [49]. In contrast, customer service personnel in the public hospitals were unable to suppress their emotional expressions while serving an excessive number of patients who generally come from the lower social class [50]. Interestingly, this did not result in a high turnover rate because of the socio-economic condition of the country, where the unemployment rate is high and people need a job. However, the excessive workload and disorganised way of managing a huge number of patients has resulted in a high level of employee burnout which is reflected in their unprofessional behaviour and unfriendly attitude towards the customers [25] [42].

Interestingly, in response to these challenges, the appropriateness of aesthetic skills and emotional labour in the healthcare sector has been questioned by a few critics. For example, how important it is for customer care staff to wear bright, colourful attire and keep smiling when addressing outpatients who require immediate medical attention, or when meeting relatives who have come to identify a missing family member's body in the hospital morgue? Is surface acting of happiness and a playful attitude suitable when faced with a severely ill patient? Larson \& Yao (2005) [51] suggested that, despite surface acting, emotional labour is essential in quality healthcare services. Theodosius (2008) [52] and Mann (2005) [53] argued that healthcare personnel should engage in empathy and deep acting instead of surface acting in a proper manner by understanding the situation of the patients and their relatives, and this should be formally recognised as a key skill in facilitating the patients' journey, with emotional skills being taught in innovative ways. Stayt's study (2008) [54] discovered that the significance of death, breaking bad news and interpersonal relationships are sources of considerable emotional stress for ca- 
regivers, and thus emotional labour requires a high level of attention and recognition. In contrast, Warhurst \& Nickson (2007) [55] and Grayson (1998) [56] argued that emotional labour compels customer care staff to express emotions that they do not truly feel and this fake attitude can often be observed by the customers, which has an overall negative effect on the service providers.

Despite the debates and arguments, the majority of researchers have agreed that sensible, empathetic behaviour with a well-groomed and professional self-presentation is desirable for the front-line customer care personnel when addressing customers [49] [57]-[59]. It is also suggestive from the above discussion that, there is a significant level of difference between the public and private hospitals in Bangladesh in terms of providing quality service encounters. To manage the challenges faced by the public hospitals in dealing with the emotional labour and aesthetic skills of the front-line customer service staff, a number of recommendations has been made by the researchers.

The first and foremost suggestion is to administer effective human resource management (HRM) practices. HRM is essential in ensuring the efficient acquisition of healthcare staff, providing them with specialised customer service training, then outlining the appropriate job duties and responsibilities, and revising the existing low pay-scale [60]. As public hospitals have a skills deficit, especially in terms of the soft skills that are essential for customer services, the person-organisation fit or person-brand fit could be an employee acquisition strategy which may help to reduce the skills deficit. These strategies were proposed by Hurrell \& Scholarios (2011) [61] in their research on the interactive service industry with a special focus on hospitality, which perhaps be used for interactive healthcare occupation. Furthermore, the "zone of tolerance" framework suggested by Liljander \& Strandvik (1993) [62] can be used to design specialised technical and interactive training programmes. The zone of tolerance represents a range of confirmation within which a customer service staff member will display respectful, helpful and professional behaviour by understanding the specific needs of the customers [62]. The practice of HRM in healthcare also seeks to improve the retention rate of healthcare personnel. Given that with sufficient resources any country can obtain the same physical capital and consumables, it is clear that the main differentiating input is the medical professionals and staffs. This is the input that is the most difficult to develop, manage, motivate, maintain and retain, and this is why the role of HRM professionals is so critical. Considering the significant changes that the growth of healthcare facilities can introduce in the country, it is important that HRM professionals be involved at the highest level of strategic planning, and not merely be positioned at the more functional, managerial levels. By being actively involved at the strategic levels, they can ensure that the HR issues are raised, considered and properly addressed.

Additionally, on a larger scale, social incentives like the public dissemination of information on the quality of service encounters can be envisaged to focus on the extent to which quality standards are being met by the hospitals [49] [63]. Similar to developed countries, a ranking or point based mechanism to rate the quality of the services of public and private hospitals could be introduced so that healthcare customers are able to make more informed choices based on the evaluations [28]. A healthcare satisfaction index can also be constructed to allow periodic comparisons with other interactive service sectors. These evaluations and quality ratings should be done by independent authorities composed of healthcare professionals, academics and researchers, and technical analysts, which will further be monitored by a highly-experienced team of expertise appointed by the government.

Customer service personnel and support staff are vital to the success of any service organisation, as the research suggests that "satisfied employees make for satisfied customers" [28]. So, regulatory incentives can be designed to reward the development of skilled manpower and customer service excellence in private hospitals [10] [28], which may boost the level of satisfaction of the front-line employees. Rahman \& Capitman (2012) [31], Hadley \& Roques (2007) [63], and Begum et al. (2000) [46] suggested a macro level utilisation of allocated government funds through stronger administrative and managerial orientation which may reduce or eliminate corruption. A high level of resource allocation to public hospitals and different level of health facilities should be considered by the government. More facilities should be allocated to patient treatment through a structured system of resource allocation, where mismanagement and corrupt practices at all levels should be strictly handled through quality assurance, effective supervision and punitive measures against those involved. Furthermore, adequate campaigns for establishing the employer brand image that might attract qualified people to work in the front-line is also suggested by these researchers. Most importantly, the proper combination of all of these recommendations is necessary to achieve high quality service encounters, and this can be achieved through the appropriate facilitation of HRM — an important way to integrate humans with other resources. 


\section{Conclusions}

"You never get a second chance to make a first impression".

Though this famous quote is of unknown origin, it correctly shows that, once a first impression has been formed, it is very hard to alter the picture and make customers change their mind. The only way to create a long lasting impressive image for customers is by undertaking emotional labour which helps us to understand and satisfy the customer needs, alongside the use of aesthetic skills to look good and sound right. This paper acknowledges that emotional labour and aesthetic skills are soft skills and that it "is not simply a 'humpty dumpty' term, but instead can have real meaning" [9]—a notion which is intertwined with healthcare interactive service occupation. This paper further agrees that, despite the challenges related to managing emotional labour and aesthetic skills in public hospitals in Bangladesh, these terms cannot be underestimated or overlooked by any means. Patient satisfaction should be indispensable to the assessments of the quality, and also to the design and management of healthcare systems; otherwise, the consequences are grim. Healthcare system in Bangladesh needs to be dynamic to keep pace with consumers' changing demands and needs. This indicates that consumers' perceptions, attitudes, suggestions and concerns need to be taken into consideration for both public and private hospitals. In conclusion, this paper strongly believes that the appropriate management of emotional labour and aesthetic skills should guide organisations towards success by instigating quality service encounters between satisfied customers and happy front-line care personnel.

\section{References}

[1] Nickson, D., Warhurst, C. and Dutton, E. (2005) The Importance of Attitude and Appearance in the Service Encounter in Retail and Hospitality. Managing Service Quality, 15, 195-208. http://dx.doi.org/10.1108/09604520510585370

[2] Yee, R.W.Y., Lee, P.K.C., Yeung, A.C.L. and Cheng, T.C.E. (2013) The Relationship among Leadership, Goal Orientation, and Service Quality in High-Contact Service Industries: An Empirical Study. International Journal of Production Economics, 141, 452-464. http://dx.doi.org/10.1016/j.ijpe.2011.12.012

[3] Zeithaml, V.A. and Bitner, M.J. (2003) Services Marketing: Integrating Customer Focus across the Firm. 3rd Edition, Irwin McGraw-Hill, New York.

[4] Büyüközkan, G., Çifçi, G. and Güleryüz, S. (2011) Strategic Analysis of Healthcare Service Quality Using Fuzzy AHP Methodology. Expert Systems with Applications, 38, 9407-9424. http://dx.doi.org/10.1016/j.eswa.2011.01.103

[5] Ali, S.H.S. and Ndubisi, N.O. (2011) The Effects of Respect and Rapport on Relationship Quality Perception of Customers of Small Healthcare Firms. Asia Pacific Journal of Marketing and Logistic, 23, 135-151. http://dx.doi.org/10.1108/13555851111120452

[6] Anderson, G.F., Frogner, B.K., Johns, R.A. and Reinhardt, U.E. (2006) Health Care Spending and Use of Information Technology in OECD Countries. Health Affairs, 25, 819-831. http://dx.doi.org/10.1377/hlthaff.25.3.819

[7] Taylor, S.A. and Cronin Jr., J.J. (1994) Modeling Patient Satisfaction and Service Quality. Journal of Health Care Marketing, 14, 34-44.

[8] John, J. (1992) Patient Satisfaction: The Impact of Past Experience. Journal of Health Care Marketing, 12, 56-64.

[9] Hurrell, S.A., Scholarios, D. and Thompson, P. (2013) More than a "Humpty Dumpty” Term: Strengthening the Conceptualization of Soft Skills. Economic and Industrial Democracy, 34, 161-182. http://dx.doi.org/10.1177/0143831X12444934

[10] Andaleeb, S.S. (2001) Service Quality Perceptions and Patient Satisfaction: A Study of Hospitals in a Developing Country. Social Science and Medicine, 52, 1359-1370. http://dx.doi.org/10.1016/S0277-9536(00)00235-5

[11] Directorate General of Health Services (DGHS) (2010) Secondary and Tertiary Health Care Facilities in Bangladesh. Ministry of Health and Family Welfare, Government of Bangladesh, Dhaka.

[12] Judge, T.A., Woolf, E.F. and Hurst, C. (2009) Is Emotional Labor More Difficult for Some than for Others? A Multilevel, Experience-Sampling Study. Personnel Psychology, 62, 57-88. http://dx.doi.org/10.1111/j.1744-6570.2008.01129.x

[13] Brotheridge, C.M. and Lee, R.T. (2003) Development and Validation of the Emotional Labour Scale. Journal of Occupational and Organizational Psychology, 76, 365-379. http://dx.doi.org/10.1348/096317903769647229

[14] Hochschild, A.R. (1983) The Managed Heart: Commercialization of Human Feeling. University of California Press, Oakland.

[15] Gelade, G.A. and Young, S. (2005) Test of a Service Profit Chain Model in the Retail Banking Sector. Journal of Occupational and Organizational Psychology, 78, 1-23. http://dx.doi.org/10.1348/096317904X22926 
[16] Williams, E.S. and Skinner, A.C. (2003) Outcomes of Physician Job Satisfaction: A Narrative Review, Implications, and Directions for Future Research. Health Care Management Review, 28, 119-140. http://dx.doi.org/10.1097/00004010-200304000-00004

[17] Guerrier, Y. and Adib, A. (2003) Work at Leisure and Leisure at Work: The Emotional Labour of Tour Reps. Human Relations, 56, 1399-1417. http://dx.doi.org/10.1177/00187267035611006

[18] Burns, P. (1997) Hard-Skills, Soft-Skills: Undervaluing Hospitality’s Service with a Smile. Progress in Tourism and Hospitality Research, 3, 239-248. http://dx.doi.org/10.1002/(SICI)1099-1603(199709)3:3<239::AID-PTH80>3.0.CO;2-2

[19] Payne, J. (2006) What's Wrong with Emotional Labour. SKOPE Research Paper No. 65, University of Warwick and University of Oxford. http://ora.ox.ac.uk/objects/uuid:9e97dbbd-ff7f-47d2-8d97-0d4dba837517

[20] Coleman, L. (1999) The Realities of Work. Academy of Management Review, 24, 362-364.

[21] Bolton, S.C. (2004) Conceptual Confusion: Emotion Work as Skilled Work. In: Warhurst, C., Grugulis, I. and Keep, E., Eds., The Skills That Matter, Palgrave Macmillan, Basingstoke.

[22] Fleming, P., Harley, B. and Sewell, G. (2004) A Little Knowledge Is a Dangerous Thing: Getting below the Surface of the Growth of Knowledge Work in Australia. Work, Employment and Society, 18, 725-747. http://dx.doi.org/10.1177/0950017004047951

[23] Nickson, D., Warhurts, C., Witz, A. and Cullen, A.M. (2001) The Importance of Being Aesthetic: Work, Employment and Service Organisation. In: Sturdy, A., Grugulis, I. and Wilmott, H., Eds., Customer Service-Empowerment and Entrapment, Palgrave, Basingstoke.

[24] Warhurst, C. and Nickson, D. (2001) Looking Good and Sounding Right: Style Counselling and the Aesthetics of the New Economy. Industrial Society, London.

[25] Siddiqui, N. and Khandaker, S.A. (2007) Comparison of Services of Public, Private and Foreign Hospitals from the Perspective of Bangladeshi Patients. Journal of Health, Population, and Nutrition, 25, 221-230.

[26] Rahman, M.M., Shahidullah, M., Shahiduzzaman, M. and Rashid, H.A. (2002) Quality of Health Care from Patient Perspectives. Bangladesh Medical Research Council Bulletin, 28, 87-96.

[27] Sen, B. and Acharya, S. (1997) Health and Poverty in Bangladesh. World Health, 50, 28-29.

[28] Akter, M.S., Upal, M. and Hani, U. (2008) Service Quality Perception and Satisfaction: A Study over Sub-Urban Public Hospitals in Bangladesh. Journal of Services Research, 8, 125-146.

[29] Andaleeb, S.S. (2000) Public and Private Hospitals in Bangladesh: Service Quality and Predictors of Hospital Choice. Health Policy and Planning, 15, 95-102. http://dx.doi.org/10.1093/heapol/15.1.95

[30] Khan, M.M.H., Grübner, O. and Krämer, A. (2012) Frequently Used Healthcare Services in Urban Slums of Dhaka and Adjacent Rural Areas and Their Determinants. Journal of Public Health, 34, 261-271. http://dx.doi.org/10.1093/pubmed/fdr108

[31] Rahman, M.A. and Capitman, J.A. (2012) Factors Affecting Profit Efficiency of Private Hospitals in Bangladesh: Are Urban Hospitals More Profit-Efficient? Journal of Health Management, 14, 83-96. http://dx.doi.org/10.1177/097206341201400201

[32] Al-Doghaither, A.H., Abdelrhman, B.M., Saeed, A.A.W. and Magzoub, M.E.M.A. (2003) Factors Influencing Patient Choice of Hospitals in Riyadh, Saudi Arabia. The Journal of the Royal Society for the Promotion of Health, 123, 105109. http://dx.doi.org/10.1177/146642400312300215

[33] Andaleeb, S.S. (1998) Determinants of Customer Satisfaction with Hospitals: A Managerial Model. International Journal of Health Care Quality Assurance, 11, 181-187.

[34] Babakus, E. and Mangold, W.G. (1992) Adapting the SERVQUAL Scale to Hospital Services: An Empirical Investigation. Health and Services Research, 26, 767-786.

[35] Anbori, A., Ghani, S.N., Yadav, H., Daher, A.M. and Su, T.T. (2010) Patient Satisfaction and Loyalty to the Private Hospitals in Sana'a, Yemen. International Journal for Quality in Health Care, 22, 310-315. http://dx.doi.org/10.1093/intqhc/mzq029

[36] Carrillat, F.A., Jaramillo, F. and Mulki, J.P. (2007) The Validity of the SERVQUAL and SERVPERF Scales: A MetaAnalytic View of 17 Years of Research across Five Continents. International Journal of Service Industry Management, 18, 472-490. http://dx.doi.org/10.1108/09564230710826250

[37] Parasuraman, A., Berry, L.L. and Zeithaml, V.A. (1991) Refinement and Reassessment of the SERVQUAL Scale. Journal of Retailing, 67, 420-450.

[38] Babakus, E. and Boller, G.W. (1992) An Experimental Assessment of the SERVQUAL Scale. Journal of Business Research, 24, 253-268. http://dx.doi.org/10.1016/0148-2963(92)90022-4 
[39] Carman, J.M. (1990) Consumer Perceptions of Service Quality: An Assessment of the SERVQUAL Dimensions. Journal of Retailing, 66, 33-55.

[40] Aksan, H.A., Ergin, I. and Ocek, Z. (2010) The Change in Capacity and Service Delivery at Public and Private Hospitals in Turkey: A Closer Look at Regional Differences. BMC Health Services Research, 10, Article 300.

[41] Andaleeb, S.S., Siddiqui, N. and Khandakar, S. (2007) Patient Satisfaction with Health Services in Bangladesh. Health Policy and Planning, 22, 263-273. http://dx.doi.org/10.1093/heapol/czm017

[42] Chowdhury, M.M.U. (2009) Customer Expectations and Management Perceptions in Healthcare Services of Bangladesh: An Overview. Journal of Service Research, 8, 121-140.

[43] Paul, B.K. (1999) National Health Care By-Passing in Bangladesh: A Comparative Study. Social Science and Medicine, 49, 679-689. http://dx.doi.org/10.1016/S0277-9536(99)00148-3

[44] Wickberg, S., Chene, M. and Zinnbauer, D. (2012) Overview of Corruption and Anti-Corruption in Bangladesh. Report by Transparency International.

[45] Vian, T. (2007) Review of Corruption in the Health Sector: Theory, Methods and Interventions. Health Policy and Planning, 23, 83-94. http://dx.doi.org/10.1093/heapol/czm048

[46] Begum, S.A., Ensor, T. and Dave-Sen, P. (2000) The Public-Private Mix in Health Care in Bangladesh. Research Note 17 by Health Economics Unit of Ministry of Health and Family Welfare, Government of the People's Republic of Bangladesh.

[47] Grandey, A.A., Fisk, G.M. and Steiner, D.D. (2005) Must Service with a Smile Be Stressful? The Moderate Role of Personal Control for American and French Employees. Journal of Applied Psychology, 90, 893-904. http://dx.doi.org/10.1037/0021-9010.90.5.893

[48] Pugh, S.D. (2001) Service with a Smile: Emotional Contagion in the Service Encounter. The Academy of Management Journal, 44, 1018-1027. http://dx.doi.org/10.2307/3069445

[49] Ullah, G.M.S. and Islam, M.R. (2011) Factors Influencing Consumer Service Experience in Private Hospitals: A Study from Bangladeshi Perspective. Interdisciplinary Journal of Contemporary Research in Business, 3, 138-147.

[50] McCord, C. and Chowdhury, Q. (2003) A Cost Effective Small Hospital in Bangladesh: What It Can Mean for Emergency Obstetric Care. International Journal of Gynecology and Obstetrics, 81, 83-92. http://dx.doi.org/10.1016/S0020-7292(03)00072-9

[51] Larson, E.B. and Yao, X.Y. (2005) Clinical Empathy as Emotional Labor in the Patient-Physician Relationship. The Journal of the American Medical Association, 293, 1100-1106. http://dx.doi.org/10.1001/jama.293.9.1100

[52] Thedosius, C. (2008) Emotional Labour in Health Care: The Unmanaged Heart of Nursing. Routledge, Oxon.

[53] Mann, S. (2005) A Health-Care Model of Emotional Labour: An Evaluation of the Literature and Development of a Model. Journal of Health Organization and Management, 19, 304-317.

[54] Stayt, L.C. (2008) Death, Empathy and Self Preservation: The Emotional Labour of Caring for Families of the Critically Ill in Adult Intensive Care. Journal of Clinical Nursing, 18, 1267-1275. http://dx.doi.org/10.1111/j.1365-2702.2008.02712.x

[55] Warhurst, C. and Nickson, D. (2007) Employee Experience of Aesthetic Labour in Retail and Hospitality. Work, Employment and Society, 21, 103-120. http://dx.doi.org/10.1177/0950017007073622

[56] Grayson, K. (1998) Customer Responses to Emotional Labour in Discrete and Relational Service Exchange. International Journal of Service Industry Management, 9, 126-154. http://dx.doi.org/10.1108/09564239810210488

[57] Pongsupap, Y. and Lerberghe, W.V. (2006) Choosing between Public and Private or between Hospital and Primary Care: Responsiveness, Patient-Centredness and Prescribing Patterns in Outpatient Consultations in Bangkok. Tropical Medicine and International Health, 11, 81-89. http://dx.doi.org/10.1111/j.1365-3156.2005.01532.x

[58] Mostafa, M.M. (2005) An Empirical Study of Patients’ Expectations and Satisfactions in Egyptian Hospitals. International Journal of Health Care, 18, 516-532.

[59] Zaman, S. (2004) Poverty and Violence, Frustration and Inventiveness: Hospital Ward Life in Bangladesh. Social Science and Medicine, 59, 2015-2036.

[60] Bartram, T., Casimir, G., Djurkovic, N., Leggat, S.G. and Stanton, P. (2012) Do Perceived High Performance Work Systems Influence the Relationship between Emotional Labour, Burnout and Intention to Leave? A Study of Australian Nurses. Journal of Advanced Nursing, 68, 1567-1578. http://dx.doi.org/10.1111/j.1365-2648.2012.05968.x

[61] Hurrell, S.A. and Scholarios, D. (2011) Recruitment and Selection Practices, Person-Brand Fit and Soft Skills Gaps in Service Organizations: The Benefits of Institutionalized Informality. In: Brannan, M.J., Parsons, E. and Priola, V., Eds., Branded Lives: The Production and Consumption of Identity at Work, Edward Elgar, Cheltenham.

http://dx.doi.org/10.4337/9780857938145.00013 
[62] Liljander, V. and Strandvik, T. (1993) Estimating Zones of Tolerance in Perceived Service Quality and Perceived Service Value. International Journal of Service Industry Management, 4, 6-27. http://dx.doi.org/10.1108/09564239310037909

[63] Hadley, M.B. and Roques, A. (2007) Nursing in Bangladesh: Rhetoric and Reality. Social Science and Medicine, 64, 1153-1165. http://dx.doi.org/10.1016/j.socscimed.2006.06.032 
Scientific Research Publishing (SCIRP) is one of the largest Open Access journal publishers. It is currently publishing more than 200 open access, online, peer-reviewed journals covering a wide range of academic disciplines. SCIRP serves the worldwide academic communities and contributes to the progress and application of science with its publication.

Other selected journals from SCIRP are listed as below. Submit your manuscript to us via either submit@scirp.org or Online Submission Portal.
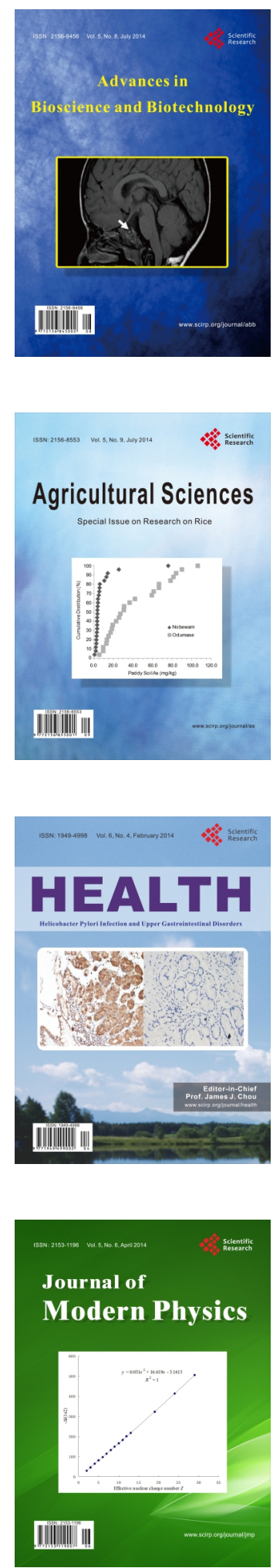
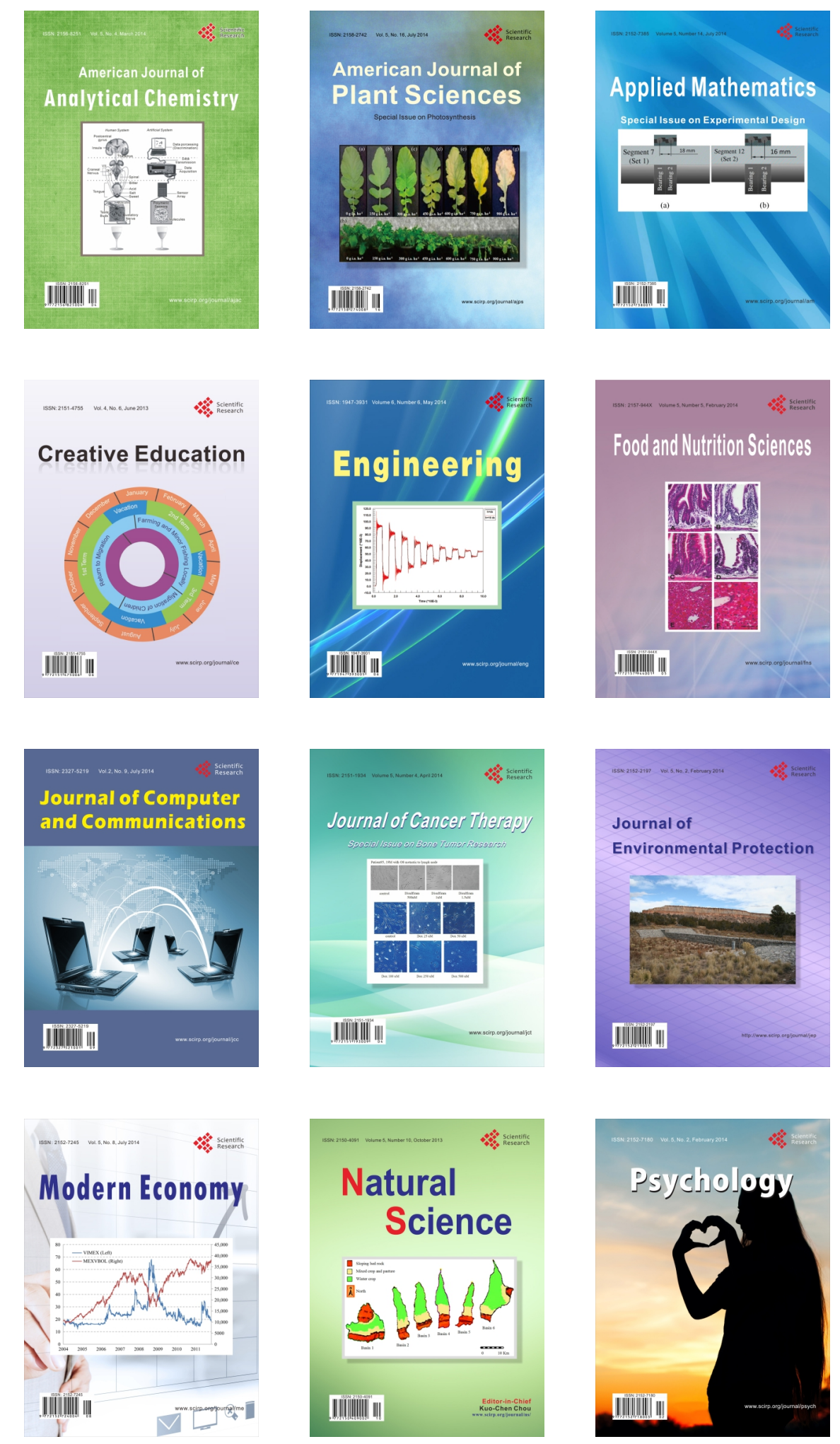